\title{
A ESCRAVIDÃO CONTEMPORÂNEA COMO OFENSA MÁXIMA À DIGNIDADE DO SER HUMANO
}

\section{CONTEMPORARY SLAVERY AS MAXIMUM OFFENSE TO HUMAN DIGNITY}

\author{
Adriana Letícia Saraiva Lamounier Rodrigues ${ }^{1}$
}

\begin{abstract}
Resumo: O presente artigo pretende realizar um estudo sociológico e jurídico da escravidão contemporânea no Brasil, especialmente a escravidão por dívida realizada nos latifúndios de nosso país. O principal objetivo é fazer um panorama sobre a realidade da escravidão brasileira, identificando-a como máximo desrespeito ao princípio da dignidade. Para tanto, vale-se da análise dos conceitos de 'trabalho escravo' e 'trabalho digno', do detalhamento do processo de escravização de trabalhadores do campo e do breve exame do aspecto penal e constitucional de tal ofensa. A metodologia adotada é a teórica-propositiva. O tema abrange uma análise em diversos campos do saber (Direito, Sociologia, Filosofia, História), o que leva a concluir que a investigação é do tipo transdisciplinar, ou seja, serão utilizados vários setores do conhecimento. $\mathrm{O}$ artigo também analisa as formas já existentes de tentativa de combate à escravidão e propõe novas possibilidades para se tentar erradicar o trabalho escravo. Será feita uma exposição da triste realidade para que tal violação seja mais eficazmente combatida.
\end{abstract}

\section{PALAVRAS-CHAVE: Escravidão contemporânea; Trabalho digno; Liberdade; Responsabilidade social.}

\begin{abstract}
This article intends to conduct a sociological and legal study of contemporary slavery in Brazil, especially debt slavery held in large landholdings of the country. The main objective is to make an overview of the reality of Brazilian slavery, identifying it as the maximum disrespect to the principle of dignity. For that, it will be analysed the concepts of 'slave labor' and 'decent job', the detailing of the enslavement of workers in the field and the criminal and constitutional aspect of such offense. The methodology adopted is the theoretical-propositive. The theme includes an analysis of several disciplines (law, sociology, philosophy, history), which leads to the conclusion that the research is transdisciplinary, ie, many areas of knowledge will be used. The article also analyzes the existing ways of trying to combat slavery and proposes new possibilities for attempting to eradicate slave labor. The study will expose the sad reality so that the violation can be more effectively tackled.
\end{abstract}

KEYWORDS: Contemporary slavery; Decent job; Freedom; Social responsibility.

\footnotetext{
1 Doutoranda em Direito do Trabalho Autonomia Individuale e Autonomia Collettiva pela Università degli Studi di Roma Tor Vergata em cotutela com a Universidade Federal de Minas Gerais. Mestrado em Master II livello Diritto del Lavoro pela Università degli Studi di Roma Tor Vergata, Itália. Especialista em Direito do Trabalho pela Università degli Studi di Roma Tor Vergata(2012).
} 


\title{
1. INTRODUÇÃO
}

O mundo atual é cheio de avanços. Nas tecnologias de ponta, no desenvolvimento econômico, de transportes, de modos de vida. O direito, de certa maneira, acompanha toda esta transição, evoluindo também. Os direitos humanos e sociais ganharam uma dimensão ímpar. O Estado de Direito, que antes era fundamentado em si mesmo, consubstancia-se com o fim de proteger o indivíduo, no traço fundamental da dignidade.

Contudo, há um fantasma que assombra o trabalhador: a escravidão contemporânea. E escravidão entendida como categoria política, capaz de designar toda e qualquer forma de trabalho não livre e indigno, como a 'exacerbação da exploração e espécie de metáfora do inaceitável’(ESTERCI, 1999, p.44). Ensina a antropóloga Neide Esterci que:

\begin{abstract}
Determinadas relações de exploração são de tal modo ultrajantes que a escravidão passou a denunciar a desigualdade no limite da desumanização. Esse, talvez, é o sentido novo da escravidão, ainda não capturado nas leis de modo eficaz, mas utilizado por representantes de segmentos os mais diferentes da sociedade quando expostos a determinadas circunstâncias. (ESTERCI, 1999, p.44)
\end{abstract}

Trata-se de campo mais que propício à batalha pela igualdade, por um capitalismo que conviva com a dignidade daqueles que subordinadamente trabalham.

No Brasil, esse espírito aviltante de exploração persiste por mais de 120 anos após a publicação oficial da Lei Áurea.

A escravidão mudou de forma, tomou outro corpo, mas tem a mesma alma. Não são mais escravos somente os negros. Nem objetos de direitos, mas sim sujeitos. Porém por outras maneiras continuam presos, acorrentados a “donos”, sem poder decidir o que fazer, como fazer e especialmente, se querem fazer. Continuam sem o poder de definir as escolhas que tomam nas suas vidas. O papel que antigamente conferia a condição de dono ao senhor do escravo mudou de cor e hoje vem em forma de notas de dinheiro, que conferem o medo da miséria, da morte de fome. As correntes que prendiam os pés dos que eram castigados mudam sua forma de ameaça e continuam quase tão eficazmente a aprisionar aqueles que as temem.

Ainda para piorar, ao invés de ser feita à luz do dia, a escravidão toma o rumo do soturno, do silêncio, do submundo que todos sabem que existe, porém fazem questão de 
ignorar. Combatê-la é tão necessário quanto difícil; contudo, deixá-la permanecer é ignorar a própria condição de ser humano daqueles que sofrem com seus desatinos.

A escravidão contemporânea é um problema por muitos ignorado, e há ainda os que a acham natural, sob o argumento de que é melhor o trabalho degradante do que o não trabalho. Frente ao monstro do desemprego, admite-se tudo. Todavia, não se percebe que com esse pensamento de se combater somente o desemprego, a dignidade do trabalhador está sendo vilipendiada:

Convivemos com total abundância, com todas as formas listadas de superexploração do trabalho. $\mathrm{O}$ trabalho em condições análogas às de escravo é tão disseminado que escapa até da pobre zona rural do norte do país, onde seria até previsível, dada a situação de miséria e de abandono da região, para cravar hipóteses de ocorrência na cidade de São Paulo. (BRITO FILHO,2004, p.135)

O fantasma da escravidão ainda não está preso nos porões das lições históricas porque seu espírito se alimenta da desigualdade social, da necessidade incessante de acúmulo de riquezas por parte de alguns, em detrimento do sofrimento de seres humanos em condição de miséria.

O presente artigo se justifica pela trágica realidade que ainda continua se espraiando pelas bordas da democracia brasileira. E, para que a teoria não seja vã, ao final do artigo propõem-se medidas práticas para se combater a escravidão contemporânea.

O Direito deve ser transformador da sociedade, e não um mero espelho.

\section{EVOLUÇÃO HISTÓRICO - JURÍDICA DA ESCRAVIDÃO EM GERAL}

A primeira notícia histórica que se tem sobre a escravidão é a dos escravos dos faraós do Médio Império em meados de 1730 antes de Cristo.

Em 1950 a.C. houve a dominação dos assírios e a escravização dos mitânicos. Também nesse período, os babilônios prenderam mulheres e filhos dos palestinos e sírios (povos estes dominados na conquista da Baixa Mesopotâmia).

Interessante dizer que o Código de Hamurabi continha algumas normas acerca do trabalho escravo. O Código dispunha, dentre outras coisas, sobre o limite de jornada dos escravos por dívidas, sobre o direito ao casamento entre livres e escravos e sobre o direito à herança. 
No período helênico, com a dominação da Grécia por Alexandre, o Grande, a escravidão continuou a ser o modo de produção predominantemente utilizado. Contudo, os filósofos estóicos já começavam a questioná-la, clamando pela igualdade entre os seres humanos. Surge daí uma primeira noção de dignidade intrínseca ao homem, somente pelo fato de ser homem. Este pensamento radical, que visava ao fim da escravidão, influirá no período áureo do Império Romano, quando os Pretores criam regras específicas para a escravidão, como a proibição de maus tratos gratuitos e o direito de escravos à herança.

Na transição da Idade Antiga para a Idade Média, ocorreu uma gradativa transformação dos escravos em servos da gleba.(SILVA, 2009, p.15)

Os servos da gleba eram considerados acessórios das terras pertencentes ao suserano. O servo e a terra eram um, eram indissociáveis.

Na Idade Média, ser um operário no sentido moderno da acepção era um estágio temporário na vida de uma pessoa, uma preparação para a maestria e para a vida adulta. O trabalho arrendado era uma exceção. (ARENDT, 2010, p.82).

Na Baixa Idade Média, com o renascimento urbano, os citadinos objetivando proteger o artesanato e o comércio de sua própria cidade, criam as corporações de ofício, associações voluntárias que regulavam a qualidade e o preço dos produtos, além do valor que seria pago aos trabalhadores. As corporações também estabeleciam as bases do aprendizado e a condição para se tornar um mestre de ofício. Neste sistema, o trabalhador detinha controle total da produção, deixava efetivamente um pouco de sua personalidade no produto final.

Após o fim da Idade Média, com a queda dos feudos e a volta das cidades, iniciase a época das navegações, a 'descoberta' dos novos mundos, primeiro a África e depois a América.

Os habitantes da América viviam livremente, dedicando-se a atividades como a caça, a agricultura, a coleta de frutas e a pesca. Tratava-se de uma sociedade pautada pela economia de subsistência. Todos trabalhavam para si mesmo.

Com a chegada dos europeus ao território americano, os índios foram submetidos à dominação. Os ibéricos tentaram impor à sociedade indígena o trabalho compulsório nas lavouras, a cultura européia e a religião católica.

No entanto, os grupos indígenas reagiram à dominação, por meio de lutas e fugas (essa última era uma reação bastante eficaz, uma vez que os índios, por óbvio, conheciam todo o território, inclusive as regiões mais remotas). Essa reação indígena ocorreu devido ao 
fato de que as sociedades indígenas americanas ignoravam estruturas hierárquicas e, consequentemente, não aceitavam o trabalho forçado. ${ }^{1}$

Diante da falta de mão de obra dócil e farta, os europeus direcionaram suas caravelas para as costas da África. Começa, assim, o trágico tráfico de mão-de-obra negra e a expansão e riqueza de seus realizadores. Navios negreiros deixam vermelhas as águas do Atlântico... Mais uma vez a escravidão veio à tona para suprir a necessidade de mão de obra intensa, de exploração das novas terras. Nesse contexto, a história do Brasil se inicia... ${ }^{2}$

Assim, formou-se na América tropical uma sociedade agrária na estrutura, escravocrata na técnica de exploração econômica, híbrida de índio e de negro na composição.

De acordo com Sérgio Buarque de Holanda (2011, p.48), “a presença do negro representou sempre fator obrigatório no desenvolvimento dos latifúndios coloniais.” E continua o sociólogo:

\footnotetext{
“A verdade é que a grande lavoura, conforme se praticou e ainda se pratica no Brasil, participa, por sua natureza perdulária, quase tanto da mineração quanto da agricultura. Sem braço escravo e terra farta para gastar e arruinar, não para proteger ciosamente, ela seria irrealizável.” (HOLANDA, 2011, p.49)
}

No período colonial vigorou o trabalho escravo por diversas razões, dentre as quais, a principal e mais óbvia era o interesse econômico. O tráfico de escravos foi um negócio bastante lucrativo para a Coroa Portuguesa.

A escravidão do negro tornou-se tão enraizada na sociedade brasileira que o trabalho braçal começou a ser visto como algo destinado e inerente ao homem de cor negra. Na sociedade da época, o trabalho era visto como uma atividade inferior (SOUSA, 2011, p.02), como algo que significava somente a submissão do homem à necessidade.

De acordo com Meillassoux, (1995, p.39) para se repor os escravos havia uma sociedade mercantil que controlava uma estrutura comercial de escoamento e distribuição. O escravo era um migrante, mesmo que especial, vindo de longe.

Na segunda metade do século XVIII, os escravos não eram mais exclusividade das lavouras, pois passaram às atividades de mineração. As condições de vida, que eram péssimas, pioraram em virtude do alto grau de periculosidade da atividade das minas. As tarefas eram duras, difíceis e perigosas.

\footnotetext{
${ }^{1}$ Antes dos estudos etnográficos mais profundos (do século XX), pensava-se que os índios eram simplesmente "inaptos" ao trabalho, tese que não se sustenta depois de pesquisas antropológicas em suas sociedades sem o impacto desestabilizador do domínio forçado.

2 No entanto, houve antes uma rica história dos nativos. Historiadores estimam que antes da chegada dos europeus havia, em território brasileiro, cerca de cinco milhões de índios.
} 
Os escravos dormiam em senzalas, espécie de porão escuro, sem higiene, e se alimentavam quase sempre de restos de comida. E sob tais degradantes condições executavam os serviços para os quais seu senhor os designava. Eram comercializados nas praças, como mercadorias. Era muito comum que quem os comprasse, normalmente um capataz do fazendeiro, analisasse os dentes do negro para auferir se eram saudáveis para o trabalho, como se faz a cavalos... As escravas mulheres se dedicavam aos afazeres domésticos, e seus filhos também eram escravos, tratados como frutos de um bem que possuía dono.

No entanto, nem sempre os negros aceitavam passivamente a dominação. Houve várias formas de resistência, como os quilombos, comunidades de escravos fugidos que tentavam sobreviver de maneira autônoma e que, quando descobertas, eram cruelmente devastadas. A mais famosa delas foi o quilombo dos Palmares, na Bahia, que teve fim trágico. Outra forma de resistir era a prática, às escondidas, das religiões africanas. Ademais, para treinar para a luta sem serem notados, os escravos astutamente inventaram a capoeira, espécie de dança que se utiliza de movimentos de luta numa bem armada coreografia. Por fim, havia a técnica das cantigas de fuga, estratégia usada para planejar como se daria o escape. Já dizia o poeta dos negros, Castro Alves (2009, p.22):

\author{
Lá na úmida senzala \\ Sentado na estreita sala, \\ Junto ao braseiro, no chão, \\ Entoa o escravo seu canto, \\ E ao cantar correm-lhe em pranto, \\ Saudades do seu torrão...
}

Os movimentos contrários ao escravagismo cresciam de maneira significativa na sociedade brasileira, chegando a ter representatividade no Congresso, em meados do século XIX, durante o período da Regência e no Reinado do monarca Pedro II, entre Republicanos e Monarquistas. Até mesmo D. Pedro I já tinha tendências abolicionistas. Afirmou ele que “ninguém ignora que o cancro que rói o Brasil é a escravatura, é mister extinguí-la”(GOMES, 2010, p.254). Declarou ainda que: 
A presença da escravidão demonstra corações cruéis e inconstitucionais e amigos do despotismo. Todo senhor de escravo desde pequeno começa olhar seu semelhante com desprezo. Um hábito que faz contrair semelhantes vícios deve ser extinto. Desse modo, os senhores olharão os escravos como seus semelhantes e assim aprenderão por meio do amor à propriedade a respeitarem os direitos do homem, que o cidadão que não conhece os direitos dos seus concidadãos, também não conhece os seus e é desgraçado toda vida. (GOMES,2010, p.255).

O Velho Continente, sobremaneira com a Revolução Francesa, inspirou ideais de liberdade e igualdade. A escravidão no Brasil era sinal de atraso.

Também não havia como negar que a economia do país era extremamente dependente do trabalho do negro escravo, uma vez que puramente agrária. Não era da noite para o dia que a escravidão seria abolida.

Pouco a pouco ares de liberdade foram pressionando as autoridades brasileiras. Em 1831, a Câmara dos Deputados promulgou uma lei que proibia o tráfico de escravos africanos. O texto foi resultado de acordo do Brasil com a Inglaterra e estabelecia que todos os escravos que entrassem no território ou portos do Brasil vindos de fora ficariam livres. Mas o ato de 1831 apesar de ter sido um primeiro passo foi ineficaz. Em 1850, foi editada a Lei Eusébio de Queirós que considerava criminosos os donos do navio, os capitães e seus subordinados, além do pessoal em terra que participasse do comércio ilícito. Finalmente ‘Colombo fechou as portas dos mares’ (ALVES,2009, p.103).

Dando continuação à transição lenta e gradual do sistema de escravidão para o de mão-de-obra livre, foi promulgada em 1871 a Lei do Ventre Livre, que considerava livre todos os filhos de escravas nascidos a partir da data da publicação da lei. Em 1885, promulgou-se a Lei dos Sexagenários que concedia liberdade aos escravos com mais de 60 anos de idade (tratou-se de um arcabouço normativo nada eficiente, porque eram em número reduzido os escravos que conseguiam chegar até essa idade e libertar os poucos que atingiam os 60 era, em verdade, um benefício aos senhores de escravos, uma vez que estes queriam se ver livre desta mão-de-obra de produção limitada).

Joaquim Nabuco, o maior porta-voz do abolicionismo, declarava:

Já existe, felizmente, em nosso país, uma consciência nacional - em formação, é certo - que vai introduzindo o elemento da dignidade humana em nossa legislação, e para a qual a escravidão, apesar de hereditária, é uma verdadeira mancha de Caim que o Brasil traz na fronte. Essa consciência, que está temperando a nossa alma, e há de por fim humanizá-la, resulta da mistura de duas correntes diversas: o arrependimento dos descendentes de senhores, e a afinidade de sofrimento dos herdeiros de escravos. (NABUCO, 200, p.11) 
Finalmente, em 13 de maio de 1888, a Princesa Isabel sancionou, em nome de seu pai, a lei que pôs fim a mais de 300 anos de escravidão. Estima-se que mais de 600 mil negros foram beneficiados (JORNAL DO SENADO,1888). Cabe acrescentar que já em maio de 1888 abolicionistas como Joaquim Nabuco defendiam a necessidade de oferecer oportunidades para integrar ex-escravos à sociedade. “Ao longo da luta pela abolição foram discutidas propostas nesse sentido, como a criação de colônias agrícolas para os libertos, a desapropriação de terras não exploradas e o desenvolvimento da agricultura” (JORNAL DO SENADO,1888). Qualquer semelhança com as necessidades da contemporaneidade não é mera coincidência.

Martins (1999) afirma que o motivo da abolição foi simples: o escravo negro, que tinha de ser comprado a peso de ouro no mercado negreiro, a partir de certo momento passou a representar prejuízo para os fazendeiros... Libertar os escravos negros era, assim, uma forma de os fazendeiros se libertarem dos escravos negros. O negro foi liberto e, ao mesmo tempo, abandonado no dia 13 de maio de 1888 (MARTINS,1999, p.128). Aboliu-se a escravidão, mas o negro alforriado não tinha nenhuma proteção estatal; não havia regulamentação para as relações de trabalho que se inauguravam...

A monarquia no Brasil durou até outubro de 1889, com o advento da proclamação da República. Militares tomaram de assalto o poder no País. Sem participação ou iniciativa popular, o Brasil rumava para um governo republicano sem povo, sem tradição e com vícios iguais aos dos tempos monárquicos.

Após os governos militares, iniciou-se um período chamado de "República do Café com Leite”, na qual os Estados de Minas Gerais e São Paulo revezavam-se no cargo de presidente. Não é por acaso o nome “café com leite”, pois Minas produzia o leite, enquanto São Paulo, o café. Porém a denominação não revelava somente a alternância de poder na República, mas também o modo de economia que sustentava o País. O Brasil não deixou de ser agrário... E mais que isso, latifundiário, com grandes produtores, os coronéis, e enorme massa de trabalhadores camponeses sofrendo de péssimas condições de vida e trabalho nas lavouras e pecuária. Indústrias eram poucas e incipientes. Nossa balança comercial continuava deficitária, vez que importávamos produtos industrializados e exportávamos nossa produção rural.

Neste contexto, os antigos escravos estavam longe de verem resolvidos seus problemas. Somavam-se aos negros uma imensa massa de população pobre brasileira e os imigrantes que vinham da Europa, fugidos da guerra e sem nenhum tostão no bolso. 
Criou-se o sistema de armazéns, à época lícito, e que prendia o trabalhador ao seu patrão por dívida, forma de redução à escravidão que, não por coincidência, é a que ocorre ainda hoje em terras brasileiras. Os operários eram aliciados e trabalhavam por um salário módico; porém, eram obrigados a comprar gêneros de sobrevivência a preços abusivos nos armazéns do patrão, o que dava início a um ciclo infinito de dívidas. Enquanto deviam, eram obrigados a trabalhar. O Direito do Trabalho, à época bem mais desenvolvido na Europa, ainda era incipiente, senão quase inexistente no Brasil. Dessa maneira adentra o País ao longo século XX.

Em 1930, um golpe articulado por civis e militares dá fim ao ciclo político Minas e São Paulo e coloca na presidência da República o lendário Getúlio Vargas, “o pai dos pobres”. Vargas inicia seus longos anos de governo sob o marco da democracia. Preocupa-se sim, é verdade, com a situação dos trabalhadores, sobretudo pelo medo do comunismo, que se espalhara mundo a fora... Lembremos que os imigrantes europeus traziam consigo as ideias revolucionárias de Karl Marx e também as ideias anárquicas.

No Governo Vargas, surgem os direitos trabalhistas, em especial aos urbanos (o primeiro deles, o de greve), até que em 1943 dá vida à Consolidação das Leis do Trabalho (CLT), já em anos ditatoriais. A legislação era avançada para a época e trazia forte carga de proteção aos operários, sobretudo os citadinos. Os trabalhadores rurais mais uma vez são deixados de lado, embora tivessem sua situação melhorada, pelo ou menos em tese. Cabe lembrar que a CLT não foi uma benesse e sim uma conquista gradativa como todo direito do trabalho no mundo.

O resumo da ópera dos primeiros quinze anos varguistas no mostra um cenário de evolução, mas que ainda precisa de enormes avanços, pois o País ainda era basicamente agroexportador (embora Vargas tivesse criado duas importantes indústrias de base no País, que se tornaram exportadoras nos anos de conflito em solo europeu, a CSN e a Vale do Rio Doce).

A ditadura de Getúlio fica desgastada após a participação do Brasil na II Guerra Mundial e assim deixa o poder. Getúlio Vargas após tornar ao poder via eleição, suicida-se. Em 1956 é eleito Juscelino Kubitcheck, de perfil desenvolvimentista, quase visionário. Com o lema “50 anos em 5”,JK pretendia nos seus cinco anos de governo desenvolver a indústria brasileira em grau que demandaria 50. Os anos 50, “anos dourados”, dão a impressão de que o País tupiniquim era de fato o "país do futuro", de que as engrenagens da nova indústria nos impulsionariam rumo ao desenvolvimento. Nas artes, o Cinema Novo e a Bossa Nova, com 
ícones como João Gilberto e Vinícius de Morais, ilustravam o estado de graça em que parecia estar o País.

Contudo, como diz Vinícius de Morais, tudo se acaba mesmo na quarta-feira. A ilusão do desenvolvimento dura tanto quanto um carnaval e os anos que seguem o governo JK são de tensão e empobrecimento. O plano de tornar o Brasil um país industrial não vinga totalmente e a economia continua dependente da exportação agrícola. Os trabalhadores do campo não têm muita voz e continuam em condições péssimas de trabalho.

Em 1962 é eleito o trabalhista João Goulart (PDT), e o brasileiro torna a ficar esperançoso em melhores condições de vida e maior distribuição da riqueza. Todavia, as acusações de que Goulart seria comunista são intensificadas pelos detentores do capital, com o fito de derrubá-lo. Março do ano de 1964 assiste a mais um golpe militar, que perduraria por mais de vinte anos, de chumbo...

Parte sombria da história do Brasil, os anos dos governos militares foram testemunhas de torturas, desaparecimentos e atrocidades mil. Em 1968 ganha vida o Ato Institucional 5 (AI5), que mata milhares de brasileiros, tirando vidas. Nestes tempos sombrios todos ou quase todos são de algum modo violentados.

Mas como toda ditadura que se mantém por muito tempo, os militares no Brasil se sustentaram por uma falsa ilusão desenvolvimentista, no caso o “Milagre Brasileiro”. A classe média e os setores conservadores da sociedade eram, no seu comodismo, sustentáculos da barbárie que aqui se instaurou. Como disse Raul Seixas em sua canção Ouro de Tolo: “eu devia estar contente \porque eu tenho um emprego \sou um dito cidadão respeitável $\backslash$ e ganho quatro mil cruzeiros $\backslash$ por mês...”.

Mas, essa ilusão da de estabilidade era puro “ouro de tolo”. Quando a conta da megalomania militar chegasse, eles é que pagariam.

O desenvolvimentismo faraônico dos ditadores custou vidas e direitos dos trabalhadores. Impedidos por um aparelho repressivo violento, os operários, exerciam, muitas vezes, sua profissão sem qualquer cuidado com saúde e segurança (um exemplo marcante é o da construção civil, pois os canteiros de obras eram 'relegados a própria sorte', andaimes assistiam atônitos às quedas de quem, com seus braços, erguiam enormes arranha-céus). $\mathrm{O}$ perigo era iminente e o país foi campeão mundial de acidentes do trabalho no ano de 1974 (ORGANIZAÇÃO INTERNACIONAL DO TRABALHO,2008) A letra de Construção, de Chico Buarque de Holanda, bem descrevia esta situação: “e flutuou no ar como se fosse um pássaro\...\ e se acabou no chão feito um pacote bêbado". 
A ânsia do brasileiro por democracia era cada vez mais iminente e a força dos militares cada vez menor. Um processo de redemocratização tem início. No começo dos anos 80, milhões de brasileiros vão às ruas de blusa amarela com os dizeres "eu quero votar para presidente”, exigindo as diretas. Sindicalistas ganham força, especialmente no ABC paulista, de onde saiu, inclusive, nosso ex-presidente Lula. A exigência e a pressão por direitos trabalhistas eram exponencialmente mais fortes. No campo, sempre mais frágil, criou-se o MST, Movimento dos Sem Terra, inspirado nos grupos de luta armada anti-ditadura como o MR8 e o Var Palmares, exigindo reforma agrária e melhorias para o trabalho rural.

A cidadania exigia um novo espaço. Em 1988, já no governo Sarney, é promulgada a Constituição da República, democrática, fundamentada na dignidade da pessoa humana. Conhecida como Constituição Cidadã, a 'jovem senhorita', hoje com 23 anos, estabeleceu como fundamentos, como núcleos basilares a cidadania, a dignidade da pessoa humana e os valores sociais do trabalho, dentre outros.

Pela primeira vez na história do Brasil, a Constituição centra-se na dignidade do ser humano. Como consequência há o objetivo de se propiciar a todo cidadão um trabalho digno, que tenha como fim a própria realização do indivíduo e não o intuito obsessivo do lucro. O texto constitucional dá uma dimensão ímpar aos direitos sociais básicos, algo inédito no constitucionalismo brasileiro.(BONAVIDES,2006, p.55)

Em termos justrabalhistas, a Constituição de 1988 deu um passo social memorável, vez que o artigo $7^{\circ}$, em 34 incisos, garantiu aos trabalhadores urbanos e rurais relevantes direitos sociais. Também garantiu a Carta Magna a livre associação sindical, o direito de greve, a participação nos lucros e a cogestão em empresas com mais de duzentos empregados.

A tendência de constitucionalização do Direito do Trabalho, iniciada, de certa forma, com a Constituição de 1934, atingiu seu ápice em 1988. Nas palavras de Maurício Godinho Delgado:

\footnotetext{
tal tendência adquiriu novo status apenas com a Carta Magna de 1988. É que esta, em inúmeros de seus preceitos e, até mesmo, na disposição topográfica, de suas normas ( que se iniciam pela pessoa humana, em vez do Estado), firmou princípios basilares para a ordem jurídica, o Estado e a sociedade - grande parte destes princípios elevando ao ápice o Trabalho, tal como a matriz do pós-guerra europeu.(DELGADO, 2009, p. 76)
}

No entanto, muito embora em termos legislativos a Constituição de 88 seja prenhe de inúmeros avanços, o que se constata defronte à realidade é demais diverso. Os direitos dos 
trabalhadores, agora erigidos a direitos fundamentais, têm sido frequentemente descumpridos, desde um adicional de hora extra até o mais a redução de alguém à escravidão. E a última é mais comum do que aparenta aos nossos olhos. Quando ocorre, descumprem-se não somente direitos trabalhistas em sentido estrito, mas também seus direitos a liberdade e a dignidade.

É de se lamentar que, mesmo com todos os avanços constitucionais, os direitos trabalhistas ainda carecem de eficácia social. Devem ser vistos pela sociedade como o são pela Constituição, como fundamentais, consectários daqueles que trabalham. Ninguém, hoje em dia, questiona o valor do direito à vida, pois que absoluto, na quase maioria dos casos espontaneamente preservado. É um consectário natural daqueles que vivem. Os direitos laborais deveriam ser vistos assim pela sociedade: inerentes àqueles que trabalham, condição da própria personalidade.

A Constituição deve ter o escopo de mudar pensamentos e costumes através da imposição de suas normas protetivas da pessoa humana, nas quais se incluem as trabalhistas. Este é um árduo trabalho que exige educar um todo populacional no sentido de zelo e cuidado no cumprimento das normas fundadoras do Estado. Isto é sinal de que a "jovem senhorita” precisa ainda amadurecer, para tornar-se senhora do comportamento social.

A dominação à qual permaneceram submetidos os negros mesmo após a Lei Áurea e a fragilidade das leis que regulavam as relações laborais dos campesinos propiciaram a construção do perfil do trabalho escravo contemporâneo.

\section{FORMAS DE PRECARIZAÇÃO DERIVADAS DA TERCEIRIZAÇÃO}

No conceito de Mauricio Godinho Delgado, no Direito do Trabalho, a “terceirização é o fenômeno pelo qual se dissocia a relação econômica de trabalho da relação justrabalhista que lhe seria correspondente” (DELGADO,2009, p.428). A terceirização torna trilateral a relação trabalhista, vindo a ser um acontecimento profundamente conectado à flexibilização do trabalho. Primeiro terceiriza-se depois flexibiliza-se e, por fim, precariza-se.

Cabe ressaltar que há, de acordo com Viana ${ }^{3}$, duas formas de terceirização: a interna e a externa. A primeira se dá quando o empregador recorre aos prestadores de serviços para executarem tarefas dentro da empresa. Já a externa ocorre quando se contrata outra empresa para realizar funções fora da tomadora de serviços.

\footnotetext{
${ }^{3}$ Explicação de Márcio Túlio Viana em aula da Faculdade de Direito da UFMG em setembro de 2009.
} 
É fácil verificar que a precarização é da própria lógica da terceirização. Explica Márcio Túlio Viana que as empresas prestadoras de serviço, como não têm condições de automatizar sua produção, acabam sendo forçadas a precarizar as relações de trabalho, para que, com a diminuição do custo da mão de obra, ofereçam seus serviços a um preço mais acessível, ganhando, assim, a concorrência perante outras empresas prestadoras de serviços. (VIANA;RENAULT;DIAS,2003).Naturalmente, não se trata de justificativa- mas de constatação de um fato econômico.

Afirma ainda Viana que:

A par de acentuar a especialização - que pode, eventualmente, até melhorar a qualidade do produto - essa terceirização externa permite à grande empresa não apenas reduzir os custos, in genere, nem somente se especializar no foco de suas atividades, mas, sobretudo, explorar em níveis desumanos a força-trabalho, valendose de suas parceiras. (VIANA; FONSECA,2010, p.10)

Jorge Luiz Souto Maior assevera que “a terceirização cria o fetiche de que a exploração do trabalho alheio não se insere no contexto de atividade do 'tomador de serviço'”, (SOUTO MAIOR, 2010, p.48). O fenômeno da terceirização oficializa, legitima a precarização das relações de trabalho, torna natural a transformação da força do trabalho em mercadoria.

A terceirização cria uma lógica de maior produção eficaz e lucrativa, tornando a exploração em cadeia uma conseqüência natural. Quanto mais se delega, mais tênue se torna a responsabilidade social da empresa e mais 'legítima' a desumanização no ambiente de trabalho da base:

É como se o capitalismo para se desenvolver, não mais precisasse da exploração do trabalho humano. A exploração se desloca do capital para o nível dos descapitalizados, que se exploram mutuamente, principalmente quando as empresas de prestação de serviços não são nada mais do que a transformação aparente do “capataz” em “empresário”. (SOUTO MAIOR, 2010, p.48)

Um caso (SOUTO MAIOR, 2010, p.50) interessante é o de um grupo sucroalcooleiro (Cosan) do Brasil que foi incluído na 'lista suja' pelo MTE pela utilização de trabalho em condições análogas às de escravo em sua rede de produção. A defesa da Cosan pautou-se pelo típico argumento que advém da perversidade da terceirização, alegando que quem era a responsável por aqueles trabalhadores era a “empresa” José Luiz Bispo Colheita ME (sendo que o Sr. José era meramente um agenciador de mão de obra com condição econômica precária), que prestava serviços na usina. 
Analisando-se o caso, percebe-se que a empresa utilizou-se do fenômeno da terceirização para se livrar da responsabilidade de ter propiciado condições degradantes a 42 trabalhadores. Assim, todo o sistema concluiu que o mal fora promovido unicamente pela empresa terceirizada. E, ampliando-se o raciocínio, é até provável que se venha a dizer que os verdadeiros culpados pela situação tenham sido os próprios trabalhadores. Afinal, teria havido um contrato verbal entre eles e o empregador.

Esse caso demonstra que a terceirização impõe uma lógica de violação aos direitos sociais, valendo-se da sutileza de se apresentar, meramente, como técnica moderna e inevitável de produção.(SOUTO MAIOR,2010, p.51)

À medida que se avança aos fios mais tênues da rede, as empresas vão se tornando menos visíveis. O que a macro-empresa não pode fazer, as micro-empresas fazem, tendo em vista sempre o maior lucro e o menor gasto possível com a manutenção de trabalhadores ${ }^{4}$.

Um dos mais graves efeitos da terceirização é justamente a ocorrência de trabalho análogo ao de escravo na base da cadeia de produção. Toda a produção torna-se maculada com o sofrimento de trabalhadores coisificados, sujeitos a condições de indignidade máxima.

\section{ESCRAVIDÃO POR DÍVIDA: DETALHAMENTO, SITUAÇÕES E BREVE REFLEXÃO SOCIOLÓGICA}

“O estigma moderno da escravidão não é a cor, mas a pobreza e o desemprego. ${ }^{5}$ ” (FIGUEIRA,2001)

A escravidão por dívida se dá, principalmente, no âmbito rural. As mais comuns são as atividades sucroalcooleira, carvoaria, pecuária, extração de madeira, lavouras (café e feijão).

Para realizar o trabalho, o fazendeiro, em geral, alicia, por meio de agenciadores de mão de obra (os 'gatos'), trabalhadores de outra região. Os gatos fixam todas as regras da relação jurídica estabelecida entre o trabalhador rural e o empregador, aparentam ser agradáveis e fazem propaganda de um bom serviço. Pagam-se o transporte até a fazenda, geralmente em caminhões, a conta nas pensões e até oferecem um “adiantamento” para a família. Uma vez transportados até a fazenda, os recrutados são informados de que só poderão sair após pagar o ‘abono’ recebido no ato do recrutamento e os gastos com o

\footnotetext{
${ }^{5}$ Frase afirmada em um discurso proferido por Ricardo Rezende Figueira.
} 
transporte, a hospedagem e a alimentação efetuados no transcurso da viagem. A dívida aumenta, pois eles devem adquirir sua alimentação e os instrumentos de trabalho de uma cantina na própria fazenda, onde os preços são bem mais altos do que os de mercado. Essa aquisição de gêneros alimentícios nos mercados dos fazendeiros é o chamado 'sistema de barracão’ ou truck- system.

Observa Jairo Lins de Albuquerque Sento-Sé (2001, p.49) que o truck-system:

\begin{abstract}
"Muitas vezes costuma se constituir num abuso por parte do empregador, pelo fato de ele efetuar o pagamento somente através da concessão de bens in natura, entregando-os por meio de vales a serem descontados do salário no final do mês. Este abuso se amplia quando o patrão, valendo-se da boa-fé e da falta de discernimento do empregado rural, obriga-o a adquirir os referidos bens ao invés de receber a contraprestação em pecúnia e os vende por preços bem acima do de mercado, aumentando de forma considerável e ilegal a dívida do obreiro.”
\end{abstract}

Ressalte-se que esta prática é terminantemente proibida no Direito do Trabalho. A Convenção $\mathrm{n}^{\circ} 95$ da OIT estabelece que nenhuma empresa poderá pressionar trabalhadores para que comprem produtos em suas lojas; e, quando lhes faltar alternativa, as autoridades devem tomar medidas para que "as mercadorias sejam fornecidas a preços justos e razoáveis” ou sem fins lucrativos. A CLT em seu artigo $462, \S 2^{\circ}$, proíbe que a empresa mantenha armazém para a venda de mercadorias quando realizada por induzimento ou quando tenha objetivos de lucro. (SENTO-SÉ,2001, p.50)

A eficiência do sistema de coerção depende de diversos fatores, tais como a responsabilidade moral sentida pelos trabalhadores diante da dívida e a presença de homens armados. A vulnerabilidade das pessoas aumenta pelo isolamento geográfico e pela ausência de família, parentes, amigos, uma vez que os empregados são retirados de suas cidades e levados a outros municípios e até estados.

Moses Finley (1991) afirma que o escravo é sempre um estrangeiro desenraizado, sem relações familiares, um estrangeiro absoluto.

Ricardo Rezende Figueira (2004, p.35) observa que:

\footnotetext{
“A relação de trabalho, a que esta tese se refere, muitas vezes vem acompanhada por um conjunto de práticas que podem ser, dependendo da autoridade coatora, tipificadas como crime - manter pessoa em cárcere privado, violência física, como a tortura, lesões corporais, assassinato - e violações às leis trabalhistas - não assinatura de Carteira de Trabalho e Previdência Social, não recolhimento dos direitos previdenciários, não pagamento do salário e das férias, condições inadequadas de habitação, transporte, alimentação e segurança.”
} 
Declara Martins que, no caso brasileiro, o núcleo da relação escravista estaria na violência em que se baseia, nos mecanismos de coerção física e também nos mecanismos de coerção moral utilizados por fazendeiros e capatazes para subjugar o trabalhador. Adicionalmente, ela surgiria quando o trabalhador, por não receber o salário que lhe é devido e por estar trabalhando em local que representa confinamento (caso da mata nas extensas fazendas da Amazônia), fica materialmente subjugado ao patrão e impossibilitado de exercer seu direito de homem livre e igual, que está no direito de ir e vir, direito de sair de um emprego e ir para outro. (FIGUEIRA,2004, p.162)

Tem-se que a maioria dos trabalhadores aliciados vem do Maranhão, Piauí, Tocantins e Pará; quase todos são homens (98\%), entre 18 e 40 anos (75\%), desqualificados e vulneráveis.(AUDI,2006)

A saga do escravo é triste:

\begin{abstract}
"Fomos oitenta pelo mundo, por três dias, sem comer. Fui porque achei influência bonita. (...) Levamos uma galinha frita, depois de Terezina, tínhamos comido tudo. A maioria era gente nova. Tinha muito molecote, gente mais nova do que eu. Passei 120 dias e voltei. (...) Fomos para a fazenda Rio Vermelho. Toda fazenda tem pistoleiro e lá tinha também. O peão pisa na bola quando compra na cantina e foge. Em 1982, fui com outros 14 peões para a fazendo São José, do Enok. Ficamos só 15 dias. A gente trabalhava, mas não pagavam”6 (FIGUEIRA, 2004, p.59)
\end{abstract}

Como nota Sento-Sé (2001, p.45), os gatos os libertam da dívida, mas em seguida os prendem de novo.

A partir da entrevista dada por José Rosa, notam-se duas fases no processo de escravização de um trabalhador: a primeira, a venda de um sonho, de um bom emprego, um bom salário, gente nova, disposta a trabalhar e subir na vida; a segunda, a desilusão da crua realidade, por meio da cobrança dos “adiantamentos” recebidos pelos operários, além do interminável endividamento causado pela compra nos armazéns dos patrões. Aí se forma o escravagismo: esvai-se a liberdade, e com ela a condição própria de ser humano; entra em cena um indivíduo animalizado, que vale o quanto deve, e está preso à terra até quando deve.

A escravidão por dívida subverte toda a ordem do trabalho prezada pelo Estado brasileiro. Nela, os trabalhadores moram em alojamentos precários, amontoam-se vários onde cabem poucos, dormem mal, descansam mal e trabalham muito. A alimentação é precária, longe do suficiente para sustentá-los. Não há assistência médica nem saneamento básico ou

\footnotetext{
${ }^{6}$ José Rosa, ex escravo, entrevistado por Ricardo Rezende Figueira.
} 
qualquer outra medida de higiene. O serviço é desenvolvido "na vara”, com maus tratos e violência e as jornadas são exaustivas, sem nenhum controle.

Infelizmente, a causa da ocorrência da escravidão por dívida é tão profunda que a maioria dos escravos resgatados ao invés de retornar ao lar, volta para fazendas escravagistas, é aliciada novamente pelo 'gato', muitas vezes devido à fome e miséria (realidade presente na vida de um número considerável de brasileiros).

Nas reflexões de Márcio Túlio Viana (2007, p.44):

Mesmo depois de liberto, e mesmo com dinheiro no bolso, nem sempre o trabalhador volta ao seu lugar de origem: seja por se sentir fracassado, seja por falta de esperança, seja porque as políticas de reinserção ainda engatinham, ou ainda porque a saída de casa teve outras razões, o melhor pode ser ficar no trecho ${ }^{7}$. E é nesse ponto que - tal como em 1888 - essa nova abolição encontra em si mesma os seus limites.

\section{TRABALHO DIGNO E A INDIGNIDADE DA ESCRAVIDÃO}

Todo e qualquer trabalhador possui o direito fundamental ao trabalho digno. O próprio Direito do Trabalho nasce e evolui a partir da consciência da importância do trabalho prestado em condições de dignidade.

Gabriela Neves Delgado (2006) assevera que o direito ao trabalho, condição essencial do homem, é capaz de honrá-lo como pessoa e de integrá-lo na sociedade, quando prestado dignamente.

Acrescenta ainda que quase toda atividade de trabalho humano pode ser potencialmente capaz de dignificá-lo (com a exceção do trabalho escravo, por exemplo), tornando possível uma reconstrução do conceito do Direito do Trabalho.

O trabalho deve propiciar ao homem a grandeza de ser humano, com o fim de libertá-lo e dignificá-lo.

Ensina a professora Gabriela Neves Delgado (2006, p.200) que, se existe um direito fundamental, deve existir também um dever fundamental de proteção.

A referida professora propõe uma reconstrução jurídica da proteção ao trabalho, baseando-se na orientação filosófica de que todo trabalho digno deve ser efetivamente protegido pelo Direito do Trabalho. E assim apenas o trabalho exercido em condições dignas consiste num instrumento capaz de construir a identidade social do trabalhador. 
Para se preservar a dignidade do trabalhador, os direitos de indisponibilidade absoluta devem ser considerados como um “patamar civilizatório mínimo”, na expressão de Maurício Godinho Delgado.

A indisponibilidade do direito ao trabalho digno é também considerada regra prevalecente no Direito do Trabalho brasileiro. Isso pode ser verificado, por exemplo, nos artigos $9^{\circ}$ (nulidade dos atos que desvirtuam ou fraudam preceitos justrabalhistas), 444 (as estipulações dos contratos não podem ser contrárias às disposições de proteção ao trabalho) e 468 (as alterações das condições dos contratos individuais não podem resultar prejuízos diretos ou indiretos ao empregado) da Consolidação das Leis do Trabalho.

Os tratados e convenções internacionais, a Constituição Federal e a CLT revelam um prisma ético, vez que exaltam a condição do ser humano e afirmam o direito de viver em elevadas condições de dignidade.

O Direito do Trabalho brasileiro deve primar pela dignidade em todas as relações de trabalho, pela inclusão socioeconômica, pela igualdade entre todos os tipos de trabalhadores, por uma 'sedimentação ética’(DELGADO, Gabriela, 2006) do trabalho, enfim, por uma efetiva proteção do hipossuficiente.

De acordo com Gabriela N. Delgado (2006, p.221):

\footnotetext{
“a igualdade, no tocante ao direito de proteção normativa de toda e qualquer relação trabalhista, revelar-se-á na construção de um sistema jurídico capaz de legitimar o direito universal ao trabalho digno. E será este direito referência maior para a possível estabilização das relações sociais de trabalho diante do sistema capitalista contemporâneo."
}

O ambiente de trabalho deve ser um lugar de efetivação dos direitos sociais. A relação trabalhista implica confiança, dependência, ajuda, rotina e convivência; executa-se, de certo modo, no interior de uma micro-sociedade que reclama a aplicação dos direitos fundamentais. Somente pelo trabalho digno a pessoa se realiza plenamente como ser humano. O poder empregatício não pode, de maneira nenhuma, suprimi-lo.

Certo é que todo contrato de trabalho (sendo, quase sempre, um contrato de adesão) implica na retirada de uma parcela de liberdade do empregado; porém, é inadmissível que esse negócio jurídico viole a dignidade de um ser humano. Inadmissível que se instrumentalize o homem pelo trabalho, como se a pessoa fosse apenas um meio de lucro e não um fim em si.

Nas palavras de Thereza Gosdal(2007,p.71): 
“Como em qualquer outra esfera da vida em sociedade, os sujeitos do contrato de trabalho prestado em condição diversa da de empregado, estão vinculados ao respeito aos direitos fundamentais reconhecidos pelo ordenamento jurídico. Aliás, os direitos fundamentais revestem-se de especial relevância nas relações de trabalho, porque as condições de alteridade e dependência em que estas se desenvolvem tornam freqüente a sua observância.”

Infelizmente, a realidade fática é pródiga em demonstrar que o desrespeito à honra e à dignidade do trabalhador permeia a maioria das relações de trabalho. O maior exemplo é justamente a existência de trabalho escravo em pleno século XXI, num Estado Democrático de Direito.

A ocorrência da escravidão contemporânea consiste numa contínua vulneração dos direitos sociais (SCHWARZ,2008, p.73), especialmente dos direitos relacionados ao contrato de trabalho. Trata-se da violação mais severa do baluarte da democracia brasileira, o princípio da dignidade da pessoa humana.

O trabalho em condições análogas a de escravo representa o máximo nível de desrespeito à dignidade do trabalhador (GOSDAL,2007, p.134), interferindo inclusive na sua liberdade de ir e vir, em sua honra (tanto objetiva como subjetiva) e na saúde física e psicológica.

\footnotetext{
"Uma compreensão da dignidade vinculada à noção de trabalho decente e ao conteúdo de honra, tornando-se um instrumento de inclusão e de garantia de respeito aos direitos fundamentais do trabalhador, evidencia a tremenda indignidade do trabalho escravo." (GOSDAL,2007, p.147)
}

Nada mais ultrajante do que a existência do trabalho indigno, em grau máximo, em um Estado legitimado por uma Constituição fundamentada no valor social do trabalho e no princípio da dignidade do ser humano.

\section{FORMAS DE COMBATE AO TRABALHO ESCRAVO}

A realidade fática demonstra uma triste estatística: ao menos 12,3 milhões de pessoas no mundo sofrem as penas do trabalho forçado, segundo a OIT (SECRETARIA INTERNACIONAL DO TRABALHO,2005, p.96). No Brasil, a Pastoral da Terra em 2006 contabilizava 25 mil pessoas (SIMON;MELO,2006, p.48).

Como tentativa de solução de tal problema surge em 1992 o Programa para a Erradicação do Trabalho Forçado - PERFOR. Em 1995, o Grupo Executivo de Repressão ao 
Trabalho Forçado e o Grupo Móvel de Fiscalização. Em 2003, o Governo lançou o I Plano Nacional de Erradicação do Trabalho Escravo, que atualmente está em sua segunda edição. Em seguida, a Comissão Nacional de Erradicação do Trabalho Escravo - CONATRAE - com representantes dos Poderes Executivo, Legislativo e Judiciário e de vários segmentos da sociedade civil (VIANA,2007, p.48).

Em 2002, o deputado federal Paulo Rocha afirmava que "somente uma força-tarefa, reunindo poder público, Justiça, sociedade civil organizada e cada cidadão pode acabar de vez com o trabalho escravo. (...) Trata-se de uma nova campanha em favor da liberdade” (DUTRA,2003, p.55).Há que se erradicar tamanho crime contra a humanidade.

Cabe aqui citar Castro Alves (2009, p.09), o poeta dos escravos:

\author{
"O Século é grande... No espaço \\ Há um drama de treva e luz. \\ Como o Cristo - a liberdade \\ Sangra no poste da cruz".
}

Uma forma de combate é a sanção penal a quem reduzir uma pessoa à condição análoga a de escravo estabelecida no artigo 149 do Código Penal:

Reduzir alguém à condição análoga à de escravo, quer submetendo - a trabalhos
forçados ou a jornada exaustiva, quer sujeitando-o a condições degradantes de
trabalho, quer restringindo, por qualquer meio, sua locomoção em razão de dívida
contraída com o empregador ou preposto.
Pena- reclusão, de dois a oito anos, e multa, além da pena correspondente à
violência.

Segundo Bittencourt, (2006, p.486) o tipo objetivo reduzir significa sujeitar uma pessoa à condição deprimente e indigna. É a submissão total de alguém ao domínio do sujeito ativo, que o reifica.

Complementa o penalista que “a sujeição completa de uma pessoa ao poder da outra suprime, de fato, o status libertatis, caracterizando a condição análoga à de escravo, embora o status libertatis, de direito, permaneça inalterado”. (BITTENCOURT,2006, p.487)

Quase sempre, o fim da conduta delitiva é a execução de trabalho em condições desumanas, indignas. E o tipo subjetivo é representado pelo dolo, sem exigência de nenhum especial fim de agir no caso do caput.

Cabe mencionar que esse artigo ganhou a sua redação definitiva com a edição da Lei 10.803 que, nas lições de Bittencourt: 
(...) pretendendo ampliar a sua abrangência e reforçar a proteção penal dos bens jurídicos tutelados , explicitou os meios e as formas pelos quais esse crime pode ser executado: quando a vítima for submetida a trabalhos forçados ou à jornada exaustiva, quer sujeitando-o a condições degradantes de trabalho, quer restringindo, por qualquer meio, sua locomoção em razão da dívida contraída com o empregador ou preposto. (BITTENCOURT, 2006, p.493)

Note-se que o mencionado artigo abrange não só situações de falta de liberdade em sentido estrito, como o trabalho em jornada exaustiva e em condições degradantes.

Quanto à expressão “condições degradantes”, de acordo com o professor Márcio Túlio Viana (2007, p.45), o melhor é entendê-la sob um enfoque não muito amplo - o que não significa reduzi-la aos casos típicos de escravidão. De acordo com ele, seriam cinco as hipóteses previstas:

A primeira categoria de condições degradantes se relaciona com o próprio trabalho escravo stricto sensu. Pressupõe, portanto, a falta explícita de liberdade. Não é preciso que haja um fiscal armado ou outra ameaça de violência. (...) a simples existência de uma dívida crescente e impagável pode ser suficiente para tolher a liberdade.

A segunda categoria se liga com o trabalho. Nesse contexto entram não só a própria jornada exaustiva de que nos fala o CP como o poder diretivo exacerbado, o assédio moral e situações análogas. Note-se que, embora também o operário de fábrica possa sofrer essas mesmas violações, as circunstâncias que cercam o trabalho escravocomo a falta de opções, o clima opressivo e o grau de ignorância dos trabalhadoresas tornam mais graves ainda.

A terceira categoria se relaciona com o salário. Se ele não for pelo menos o mínimo ou se sofrer descontos não previstos na lei, a inserção do nome do empregador na lista [suja] se justifica.

A quarta categoria se liga à saúde do trabalhador que vive no acampamento da empresa- seja ele dentro ou fora da fazenda. Como exemplos de condições degradantes teríamos a água insalubre, a barraca de plástico, a falta de colchões ou lençóis, a comida estragada ou insuficiente.

Mas, mesmo quando o trabalhador é deslocado para uma periferia qualquer, e de lá transportado todos os dias para o local de trabalho, parece-nos que a solução não deverá ser diferente. Basta que a empresa repita os caminhos da escravidão, desenraizando o trabalhador e não lhe dando outra opção senão a de viver daquela maneira. Essa seria a quinta categoria de condições degradantes. (VIANA,2007, p.45)

O artigo 149 do CP traz um conceito muito aberto, o que pode às vezes impossibilitar o enquadramento do efetivo trabalho forçado (este muito bem definido pela Convenção 29 da OIT). Diante disso, poder-se-ia argumentar que a mistura dos conceitos de trabalho forçado e trabalho degradante dificulta enormemente a persecução penal do escravagista.

Nas palavras da professora Lívia Mendes Moreira Miraglia (2010, p.107):

Na prática, ainda permanece na doutrina e nos Tribunais pátrios uma interpretação restritiva do conceito aduzido no art. 149 do CP, de modo que o trabalho escravo 
contemporâneo se configura apenas se verificada a ofensa ao direito de liberdade do obreiro.

De acordo com a referida professora a interpretação restritiva do conceito aduzido no referido artigo é:

(...)inadmissível em um Estado Democrático de Direito, uma vez que inviabiliza e impede a tutela plena desses trabalhadores que, além de subjugados por empregadores inescrupulosos, ainda se sentem lesados pelo Estado, incapaz de lhes garantir a entrega efetiva da prestação jurisdicional.(MIRAGLIA,2010, p.107)

Assevera ainda José Cláudio Monteiro de Brito Filho:

E qual é o fundamento que impede a coisificação do homem? A dignidade da pessoa humana. Esse o fundamento maior, então, para a proibição do trabalho em que há a redução do homem à condição análoga à de escravo. Ora, não há justificativa suficiente para não aceitar que, tanto o trabalho sem liberdade como o em condições degradantes são intoleráveis se impostos a qualquer ser humano. É preciso aceitar que o paradigma para a aferição mudou; deixou de ser apenas o trabalho livre, passando a ser o trabalho digno. A liberdade, claro, ocupa espaço, principalmente nas legislações com visão mais restrita do problema, como é o caso da convenção 29 da OIT. Contudo e felizmente, na hipótese brasileira avançamos na discussão, dando a conotação de trabalho análogo à escravidão para mais de uma forma de coisificação do ser humano. Trata-se da valorização da condição humana do homem como detentor do direito ao trabalho efetivamente digno. (BRITO FILHO, 2011, p.1360

Diante da realidade brasileira, em 2003, o Presidente Luiz Inácio Lula da Silva lançou o Plano para Erradicação do trabalho escravo.

A proposta número 9 do plano, que possui 76 medidas para a erradicação, previa a inserção de cláusulas contratuais impeditivas para a obtenção e manutenção de crédito rural e de incentivos fiscais nos contratos das agências de financiamento, quando comprovada a existência de trabalho escravo ou degradante.

A apresentação do Plano Nacional para Erradicação do Trabalho Escravo estabelece:

Consciente de que a eliminação do trabalho escravo constitui condição básica para o Estado Democrático de Direito, o novo Governo elege como uma dasprincipais prioridades a erradicação de todas as formas contemporâneas de escravidão. E o enfrentamento desse desafio exige vontade política, articulação, planejamento de ações e definição de metas objetivas. (AUDI; SAKAMOTO,2011)

Assim, surgiram as Portarias n. 504 do Ministério do Trabalho e Emprego e 1150 do Ministério da Integração Nacional. 
A Portaria 504 criou o cadastro de pessoas físicas e jurídicas que realizam o trabalho em condições análogas à de escravo.

Já a portaria n. 1150 definiu que o departamento de Gestão dos Fundos de Desenvolvimento Regional levasse o cadastro de pessoas físicas e jurídicas exploradoras de trabalho forçado aos bancos administradores dos Fundos Constitucionais de Financiamento. Também adverte aos bancos de se absterem de conceder financiamentos às referidas pessoas físicas e jurídicas.

Interessante também foi a iniciativa privada de combate ao trabalho escravo. Cabe aqui citar a explicação do pacto nacional pela erradicação do trabalho escravo,de acordo com Patrícia T. M. Costa:

Assinado em maio de 2005, o Pacto Nacional é um compromisso voluntário assumido por cerca de 200 empresas, visando dignificar e modernizar as relações de trabalho em suas cadeias produtivas. Foram inseridas na agenda dos empresários e da sociedade brasileira medidas para dignificar, formalizar e modernizar as relações de trabalho em todos os segmentos econômicos.

As empresas signatárias do Pacto reúnem cerca de 20\% do Produto Interno Bruto (PIB) brasileiro. O Pacto se estrutura em termo dos seguintes compromissos:

- Definição de metas específicas para a regularização das relações de trabalho nessas cadeias produtivas, o que implica na formalização das relações de emprego pelos produtores e fornecedores, no cumprimento de todas as obrigações trabalhistas e previdenciárias e em ações preventivas referentes à saúde e à segurança dos trabalhadores;

- Definição de restrições comerciais às empresas ou pessoas identificadas na cadeia produtiva que se utilizam de condições degradantes de trabalho associadas a práticas que caracterizam a escravidão;

- Apoio às ações de reintegração social e produtiva dos trabalhadores que ainda se encontram em relações de trabalho degradantes ou indignas, garantindo-lhes oportunidades de superação da sua situação de exclusão social, em parceria com as diferentes esferas de governo e organizações sem fins lucrativos;

- Apoio às ações de informação aos trabalhadores vulneráveis ao aliciamento de mão-de-obra escrava, assim como campanhas destinadas à sociedade para a prevenção da escravidão;

- Apoio às ações, em parceria com entidades públicas e privadas, no sentido de propiciar o treinamento e o aperfeiçoamento profissional de trabalhadores libertados; (...)

-Sistematização e divulgação da experiência, de forma a promover a multiplicação das ações que possam contribuir para o fim da exploração do trabalho degradante e do trabalho escravo em todas as suas formas, no Brasil e em outros países;

(...).(COSTA,2010)

Outra forma bem interessante que foi recentemente aprovada (27 de maio do presente ano) pelo Congresso Nacional é o Projeto de Emenda Constitucional 57A de 1999. Tal projeto prevê um acréscimo ao artigo 243 da Constituição para possibilitar a expropriação de propriedades rurais em que seja encontrado trabalho escravo. Desde 1995 a ideia vem 
tramitando no Congresso, quando a primeira versão do texto foi apresentada pelo deputado Paulo Rocha, porém, sem sucesso. Então, algum tempo depois, o senador Ademir Andrade (PSB-PA) criou uma proposta semelhante, que foi aprovada em 2003 e remetida para a Câmara.

Eis a ementa:

\section{Ementa}

Dá nova redação ao art. 243 da Constituição Federal.

Explicação da Ementa

Estabelece a pena de perdimento da gleba onde for constatada a exploração de trabalho escravo (expropriação de terras), revertendo a área ao assentamento dos colonos que já trabalhavam na respectiva gleba. (SENADO FEDERAL, 2014).

A área expropriada será revertida a projetos de reforma agrária. Trata-se de uma efetiva e justa sanção diante da absurdidade de se reduzir outro ser humano a coisa, a objeto de exploração.

Esse Projeto de Emenda Constitucional é compatível com a sistemática da Constituição Federal de 1988, tendo em vista dois direitos fundamentais: função social da propriedade e a dignidade da pessoa humana.

A função social da propriedade está elencada no artigo 5º inciso XXIII, no artigo 182 e no artigo 186 da Constituição Federal, sendo elemento integrante do conceito de propriedade. Em virtude de não se tratar apenas de limitação do direito de propriedade, mas de elemento integrante de seu próprio conceito, o dono de bem imóvel que dá a este uma destinação incompatível e desarmoniosa com o interesse público não pode ser considerado proprietário, desnatura-se seu direito. (FERNANDES, 2010, p.289)

Nas propriedades rurais, a própria Carta Magna estabelece requisitos relacionados ao trabalho para caracterizar a socialidade da propriedade, quais sejam, observância das disposições que regulam as relações de trabalho e exploração que favoreça o bem-estar dos proprietários e dos trabalhadores (incisos III e IV do artigo 186, CF).

Como dito, o direito fundamental à propriedade engloba dois aspectos indissociáveis, o individual e o social. A PEC ao penalizar com a perda da propriedade o escravagista, nada mais faz do que reconhecer o total aniquilamento da parte social da propriedade, que, por conseqüência lógica, extirpa o próprio direito. Dessa maneira, a ordem constitucional protege 
não só a utilização socialmente consciente da propriedade como a dignidade de cada trabalhador.

\section{PROPOSTAS DE OUTRAS MEDIDAS EFETIVAS}

A realidade do trabalho escravo no Brasil é dura e silenciosa. Erradicá-la é uma tarefa que se impõe como mais do que imediata.

É preciso que diversos atores sociais participem desse processo. O Estado sozinho não dá conta. Desde uma denúncia até o boicote a produtos que utilizam mão de obra escrava em sua cadeia produtiva são medidas que qualquer cidadão pode tomar.

O Plano Nacional de Erradicação de trabalho escravo é insuficiente, por ser medida apenas estatal, sem a participação efetiva dos envolvidos no processo. Ademais, não vai à raiz do problema, somente remedia os sintomas, sem curar efetivamente o país desta doença que atende pelo nome de escravidão. Evidência ${ }^{8}$ disso é o fato de que grande parte dos resgatados retorna ao trabalho forçado. Além disso, embora as inspeções tenham se multiplicado desde 2003, metade das denúncias permanece sem fiscalização.(VIANA,2007,p.55) É que, mesmo sabedores das condições degradantes às quais são submetidos, o medo da fome e o fantasma do desemprego não deixam os trabalhadores em paz.

Diante disso, tentaremos esboçar duas outras propostas.

\subsection{Cooperativas Rurais - dever de solidariedade}

Um fato preocupante, como dizíamos, é que a maioria dos trabalhadores resgatados do trabalho escravo volta a ele depois de algum tempo. Em geral, isso ocorre devido ao desemprego, à miséria e à própria luta pela sobrevivência. Diante do medo da fome, o trabalhador volta ao local de exploração, pois o empregador escravagista contemporâneo, de alguma maneira e ainda que gerando “dívidas”, fornece comida aos trabalhadores para que eles se mantenham vivos e assim se reproduzam enquanto força de trabalho.

\footnotetext{
${ }^{8}$ De acordo com Rodrigo Garcia Schwarz, falta efetividade ao Plano Nacional para a erradicação do Trabalho Escravo, pois apenas $22,4 \%$ das suas metas foram, de fato, cumpridas, sendo que $46 \%$ das suas metas foram cumpridas parcialmente e $26,3 \%$ não foram cumpridas, falta também eficácia, pois verifica-se a reincidência de infratores e vítimas bem como a manutenção da impunidade e miséria.
} 
Dispõe o artigo $3^{\circ}$ da Constituição Federal que constituir uma sociedade livre, justa e solidária, erradicar a pobreza e reduzir as desigualdades sociais são alguns dos objetivos fundamentais da República Federativa do Brasil.

Para que sejam alcançados os objetivos acima elencados, e - mais especificamente diminuir o número de trabalhadores que reingressam ao lugar de origem, forma interessante é o estímulo do Estado à construção de cooperativas de trabalho.

Explicam Schmidt e Perius que:

\begin{abstract}
As cooperativas são associações autônomas de pessoas que se unem voluntariamente e constituem uma empresa, de propriedade comum, para satisfazer aspirações econômicas, sociais e culturais. Baseiam-se em valores de ajuda mútua, solidariedade, democracia, participação e autonomia. Os valores definem as motivações mais profundas do agir cooperativo. (SCHIMIDT; PERIUS, 2003, p.63)
\end{abstract}

As cooperativas devem ser pautadas por diretrizes que põem em prática valores como controle democrático pelos sócios, adesão plenamente livre, transparência, participação igualitária, educação, treinamento e justa remuneração dos cooperados.

Na cooperativa, a retribuição de cada cooperado deve ser superior ao ganho que ele teria, caso estivesse trabalhando isoladamente.

De acordo com Marcelo J. Braga, Antônio J. H. da Silva e Henrique L. Dornadelas (2011), “os cooperados munidos de um compromisso de solidariedade social e ajuda mútua devem cooptar esforços para o desenvolvimento e fortalecimento do empreendimento ao qual se associaram”.

A gestão coletiva da cooperativa deve ter como princípios a primazia do trabalho e a valorização do ser humano, numa perspectiva de supremacia da dignidade da pessoa humana. É alternativa ao sistema capitalista “selvagem”, de busca incessante pelo lucro, já que garante renda digna para trabalhadores marginalizados, desprezados pela sociedade.

Nesse sentido, afirmam Schmidt e Perius:

As organizações cooperativas têm como seu mais nobre valor e como contribuição específica a dar à sociedade de hoje, a contundente afirmação da primazia do trabalho sobre o capital, do homem sobre a máquina, da realização pessoal e coletiva sobre o individualismo. (SCHIMIDT; PERIUS, 2003, p.70)

A cooperativa é uma alternativa que pode garantir trabalho e renda digna para trabalhadores marginalizados, desprezados pela sociedade. 
É na economia solidária que reside o fundamento de organização dos cooperados, sendo esta o grande diferencial de comportamento dos seres humanos que se associam com o objetivo de obter ganho através da ajuda mútua, inclusiva e não exclusiva como nos leciona o capitalismo tradicional. O outro é visto como colega, como pedaço de um todo do qual o "eu” faz parte, e sem todos perecerá. Muito diferente da tradição do capital que vê o outro como concorrente e com ele disputa parcelas do mercado, palmo a palmo. Paul Singer assim define economia solidária:

O conceito se refere a organizações de produtores, consumidores, poupadores etc. que (...) (a) estimulam a solidariedade entre os membros mediante a prática da autogestão e (b) praticam a solidariedade trabalhadora em geral, com ênfase na ajuda aos mais desfavorecidos. (SINGER, 2003, p. 116)

É necessário reviver essa economia solidária nos dias atuais para que se democratize o campo da produção e da distribuição. De acordo com Singer, “a revivência da economia solidária só se torna possível pelo apoio de instituições governamentais e da sociedade civil”. (SINGER,2003, p.124)

A classe trabalhadora da América do Sul foi fragmentada junto com as cadeias produtivas, principalmente devido à precarização das relações de trabalho. Para se reverter esse processo algumas pequenas formas de reunificação já começaram a se fortalecer. Exemplo disso é o movimento dos sem-terra, de trabalhadores assalariados assim como de pequenos proprietários ameaçados pelos grandes empresários detentores de quase todo o capital.

De acordo com o professor Márcio Túlio Viana:

Vivemos um tempo em que os vazios deixados pelo Estado-Nação são reocupados não só de forma autoritária pelo grande capital, mas de modo democrático pela sociedade civil, que aos trancos e barrancos vai multiplicando as suas associações de bairros, as pequenas cooperativas de produção e as estratégias coletivas de sobrevivência. (VIANA, 2007, p.43)

Afirma José Luís Coraggio:

Como no Brasil, as centrais de trabalhadores ou as redes que pretendem representar a todos os trabalhadores devem complementar as lutas pelo salário e pelas condições de trabalho com a iniciativa de impulsionar a formação de cooperativas de trabalho e de consumo, articuladas em sistemas produtivos e reprodutivos complexos. (CORAGGIO, 2003, p.95) 
O sistema de economia solidária pode dar força efetiva aos trabalhadores para se construir uma sociedade mais igualitária, mais justa e autodeterminada.

Desse modo, o cidadão que luta pela sobrevivência não se verá mais obrigado por sua condição de miséria a se submeter a um trabalho forçado ou degradante.

Tendo as cooperativas a adesão de muitos trabalhadores, elas se tornarão fortes, constituindo efetivo obstáculo ao aliciamento de trabalhadores por "gatos" e fazendeiros latifundiários.

Naturalmente, devem ser consideradas as dificuldades de criação e manutenção de uma cooperativa, fielmente baseada na economia solidária. Até porque será uma associação que caminhará “contra a maré” (vez que seu objetivo não será a desenfreada aferição de lucro) e assim enfrentará muitos obstáculos na conquista de mercado.

\subsection{Responsabilidade social da empresa: ideia de selos que propiciam uma melhor imagem da empresa frente aos consumidores.}

A maioria das empresas - incluindo, naturalmente, as do agrobusiness- querem a todo custo acumular cada vez mais riqueza. Para isto precisam que seus produtos sejam maciçamente consumidos e, além disso, diminuir os custos de produção. Forma eficaz de fazê-lo é pagando mal ou nada aos trabalhadores. Desse modo se colocam um passo à frente de seus concorrentes, que querem cumprir a lei. Mão de obra gratuita é sempre sinônimo de ambição para quem enxerga o lucro como modo de vida a ser perseguido.

Contudo, mesmo vendendo a preço menor que o de seus concorrentes, de nada isso vale para a empresa se seu produto não for consumido. Trocando em miúdos, seu objetivo final só vai ser alcançado se vender, e vender é ato que depende dos consumidores. Nada melhor que atacar este destinatário final, quem compra produtos, para desarticular o uso de trabalho escravo. E o melhor: fazendo uso de veneno próprio do capital, qual seja, agregando valor ao produto final.

É nisto que reside a ideia da responsabilidade social da empresa, com a criação de um selo de certificação e garantia, contendo dizeres como: 'produto livre de trabalho escravo'.

De acordo com Márcio Túlio Viana (2007, p.41), “o mesmo modelo que induz o trabalho escravo acaba fornecendo instrumentos para o seu combate. A imagem da empresa, boa ou má, contamina o produto que ela fabrica e o próprio cidadão que o consome”. 
Assim como os selos ambientais que são colocados em mobílias, o fato de ter a marcenaria concorrente usado trabalho forçado pode se tornar um traço importante de diferenciação entre os dois produtos. (VIANA, 2007, p.62)

\begin{abstract}
O fenômeno da chamada responsabilidade social da empresa se insere nesse contexto. Apesar de suas reconhecidas limitações ${ }^{9}$, o que lhe garante uma eficácia crescente é, sobretudo, o valor que a imagem da marca e do produto vai adquirindo para o consumidor. É que também ele está cada vez mais preocupado com a sua própria imagem - não só física quanto imaterial. Quer parecer politicamente correto, não só aos outros como a si mesmo; e, num mundo cada vez mais desigual, compensa dessa forma o sentimento de culpa que o invade. (VIANA,2007, p.41)
\end{abstract}

No comércio justo, “o consumidor consciente adquire não apenas produtos, mas também relações de compromisso com os produtores ao ficar informado da origem do produto nos aspectos ético e ambiental”. (FRETEL; ROCCA,2003, p.33)

No Brasil, algumas empresas multinacionais seguem códigos de conduta relativos aos direitos dos trabalhadores e observam se seus contratantes respeitam esses códigos. Como vimos, a maioria delas firmou um Pacto Nacional para a Erradicação do Trabalho Escravo, comprometendo-se a não utilizar trabalho forçado, seja diretamente ou através de seus provedores.

Exemplo de monitoramento de condutas sociais das empresas é o Instituto de Observatório Social (IOS) da Central Única dos Trabalhadores(CUT).

Fundado em 1977, o Instituto é uma organização que tem por objetivo analisar e pesquisar o comportamento sócio-trabalhista de empresas multinacionais e estatais, no que se refere ao cumprimento de direitos fundamentais dos operários no Brasil. Embasado nas Convenções da OIT, o IOS estuda e fiscaliza práticas ligadas à liberdade sindical, à negociação coletiva, ao trabalho infantil, ao trabalho forçado, à discriminação de gênero e raça, ao meio ambiente, saúde e segurança ocupacional e ao impacto das trocas comerciais brasileiras no mercado de trabalho.

Para realizar seu escopo, o IOS se vale do suporte de outros institutos, como o Centro de Estudos de Cultura (Cedec), o Departamento Intersindical de estudos sócioeconômicos (Dieese), e a Rede Inter-Universitária de Estudos e Pesquisa Sobre o Trabalho (Unitrabalho). 
De acordo com o IOS, socialmente responsáveis são as empresas preocupadas em distribuir mais justamente a riqueza e diminuir a exclusão (INSTITUTO DE OBSERVATÓRIO SOCIAL, 2013) ${ }^{10}$. Além disso, devem estar abertas a dialogar sobre responsabilidade social e suas relações com o grande comércio exterior, respeitar as normas da OIT, diretrizes da OCDE e, por óbvio, coadunar suas práticas sempre à Declaração Universal dos Direitos Humanos. (INSTITUTO DE OBSERVATÓRIO SOCIAL, 2011)

As mais freqüentes violações decorrem a intensa terceirização, acarretando sempre mais precariedade nas relações de trabalho.

Existem no Brasil alguns organismos que estabelecem parâmetros para as empresas interessadas em praticar a responsabilidade social. O que mais se destaca é o Instituto Ethos (criado por empresários que tiveram o aval da CUT). Na última versão do Instituto foram introduzidos temas novos como comércio justo, assédio moral e trabalho forçado.(VIANA,2008)

Destarte, considerando o contexto mundial capitalista, baseado na economia de mercado, pode-se afirmar que utilizar a estratégia de selos sociais que valorizem o trabalho digno seja uma eficiente medida para se erradicar ou atenuar a vil exploração no trabalho.

\section{CONCLUSÃO}

Diante das exposições já feitas, claro está que a erradicação das novas versões da escravidão é questão mais do que urgente. Continuar inerte frente a essa doença grave é ser conivente com o vilipêndio da dignidade de milhares de trabalhadores, é permitir que tais práticas, em geral desenvolvidas nas atividades de base, maculem toda a cadeia produtiva.

Objetivou-se analisar sempre conceitos opostos como a escravidão e o trabalho digno. O escravismo é, pois, totalmente incompatível com os eixos fundamentais da democracia brasileira.

No decorrer do trabalho, verificou-se que a escravidão contemporânea em democracias capitalistas só pode ser explicada como um desvio de conduta de empregadores que visam à maximização dos lucros, à custa da violação da dignidade de trabalhadores paupérrimos. Trata-se de acúmulo de riqueza 'fazendo ouro dos sofrimentos inexprimíveis de outros homens'(NABUCO, 2000).

\footnotetext{
10 http://www.observatoriosocial.org.br/portal/index.php?option=content\&task=view\&id=6\&Itemid=31,
} acessado em dezembro de 2013. 
Um enfoque foi dado à escravidão por dívida, por ser esta a principal forma de escravidão no Brasil contemporâneo. É ainda mais fácil burlar as leis na vastidão dos sertões de nosso país.

Fez-se também uma explanação acerca do artigo 149 do Código Penal, do Plano Nacional para Erradicação do Trabalho Escravo e da "lista suja” criada pelo Ministério do Trabalho, como uma forma de sancionar os escravagistas contemporâneos.

Já ao final, duas outras medidas foram propostas, o incentivo à criação de cooperativas rurais e invenção de um selo social que ateste a inexistência de trabalho degradante na cadeia produtiva, tendo em vista a economia solidária e o consumo consciente e solidário, respectivamente.

A mancha da escravatura que paira sobre o Estado Democrático brasileiro deve ser removida antes que torne a Constituição letra morta. A eliminação da escravidão é, além de um dever jurídico, um dever moral de todo cidadão. E que a 'liberdade ainda que tardia tenha piedade de nossa inércia’ (RONAI, 1980, p.102) frente à tão grave violação de direitos humanos.

\section{REFERÊNCIAS BIBLIOGRÁFICAS}

ALVES, Castro. Os escravos.Porto Alegre: L\&PM, 2009.

AUDI, Patrícia. A escravidão não abolida. In: VELLOSO, Gabriel; FAVA, Marcos Neves (coord.). Trabalho Escravo Contemporâneo: o desafio de superar a negação. São Paulo: LTr, 2006.

AUDI, Patrícia; SAKAMOTO, Leonardo. Trabalho Escravo no Brasil no século XXI.Disponível em: http://www.oitbrasil.org.br/download/sakamoto_final.pdf.Acesso em: 16 jun. 2014.

ARENDT, Hannah. A condição humana. 11ª ed. São Paulo: Forense Universitária, 2010. 
BARROS, Alice Monteiro. Discriminação no emprego por motivo de sexo. In: RENAULT, Luiz Otávio Linhares; VIANA, Márcio Túlio; CANTELLI, Paula Oliveira (Coords). Discriminação. $2^{\mathrm{a}}$ ed.São Paulo: LTr, 2010.

BITTENCOURT, Cezar Roberto. Tratado de Direito Penal: parte especial, v.II. $5^{\text {a }}$ Ed. São Paulo: Saraiva, 2006.

BONAVIDES, Paulo. Curso de Direito Constitucional. Malheiros, 19a edição. São Paulo, 2006

BRAGA, Marcelo; SILVA, Antônio J. H. da; DORNADELAS, Henrique Lopes. Cooperativas de trabalho: a práxis dos princípios cooperativistas e sua análise jurídica. < http://www.ichs.ufop.br/conifes/anais/OGT/ogt1605.htm> Acesso em: 14 de maio de 2014.

BRASIL. Constituição (1988). Constituição da República Federativa do Brasil. Disponível em: <http://www.planalto.gov.br/ccivil_03/Constituicao/Constituicao.htm> Acesso em: 30 mar. 2014.

BRITO FILHO, José Cláudio Monteiro de. Trabalho decente. Análise jurídica da exploração do trabalho- trabalho forçado e outras formas de trabalho indigno.LTr, 2011.

CORAGGIO, José Luís. A economia do trabalho.In: CATANI, Antônio David (Org). A outra economia. Veraz Editores. Porto Alegre, 2003

COSTA, Patrícia T. M.Combatendo o trabalho escravo contemporâneo: o exemplo do Brasil. Brasília: $\quad 2010 . \quad$ OIT, Disponível em http://www.oitbrasil.org.br/info/downloadfile.php?fileId=447, acesso em 10 de janeiro de 2014.

DELGADO, Gabriela Neves. Direito Fundamental ao Trabalho Digno. São Paulo: LTr, 2006.

DELGADO, Maurício Godinho. Curso de Direito do Trabalho. São Paulo:LTr, 2009. 
DUTRA, Maria Zúlia Lima. Trabalho escravo no século XXI: alguns casos exemplares nos sertões do Pará e Amapá. Monografia apresentada à Coordenação de Pesquisa de Pósgraduação, Extensão e Programas Educacionais - COPEPE, do Centro de Ensino Superior do Amapá -CEAP. Macapá, 2003.

FERNANDES, Bernardo Gonçalves. Curso de Direito Constitucional. 2ª Ed. Rio de Janeiro: Lumens Juris, 2010.

FIGUEIRA, Ricardo Rezende. Pisando fora da própria sombra. Rio de Janeiro:Civilização Brasileira, 2004.

FRETEL; ROCA.Comércio justo. In: CATANI, Antônio David (Org). A outra economia. Veraz Editores. Porto Alegre, 2003.

GOMES, Laurentino. 1822.Rio de Janeiro: Nova Fronteira, 2010.

GOSDAL, Thereza Cristina. Dignidade do trabalhador: um conceito construído sob o paradigma do trabalho decente e da honra.São Paulo: LTr, 2007.

HOLANDA, Sérgio Buarque de. Raízes do Brasil. 23ª edição. São Paulo: Companhia das Letras, 2011.

JORNAL DO SENADO, Uma reconstituição histórica do dia 14 de maio de 1888 . Rio de Janeiro.

MAIOR, Jorge Luiz Souto. A Terceirização e a lógica do mal.In: SENA, Adriana Goulart de; DELGADO, Gabriela Neves; NUNES, Raquel Portugal. Dignidade humana e inclusão social. Ltr, São Paulo, 2010, p.48

MARTINS, José de Souza. A escravidão nos dias de hoje e as ciladas da interpretação. In: Comissão Pastoral da Terra (org). Trabalho escravo no Brasil Contemporâneo. São Paulo: Ed. Loyola. 1999

MEILLASOUX, Claude. Antropologia da escravidão - o ventre de ferro e dinheiro. Rio de Janeiro: J.Zahar, 1995. 
MIRAGLIA, Lívia Mendes Moreira. O combate ao trabalho escravo contemporâneo e a Justiça do Trabalho. In: SENA, Adriana Goulart de; DELGADO, Gabriela Neves; NUNES, Raquel Portugal (Coords). Dignidade Humana e Inclusão Social: caminhos para a efetividade do Direito do Trabalho no Brasil. LTr. São Paulo, 2010.

NABUCO, Joaquim. O abolicionismo. São Paulo : Publifolha, 2000.

RELATÓRIO Global do Seguimento da Declaração da OIT sobre Princípios e Direitos Fundamentais no Trabalho. Uma aliança global contra o trabalho forçado -. 93 ${ }^{\text {a }}$ Reunião. Tradução Edilson Alkmim Cunha. Genebra: SIT, 2005.

RÓNAI, Paulo. Não perca seu latim. Rio de Janeiro: Nova Fronteira, 1980, p.102. Lema da bandeira de Minas Gerais.

SCHMIDT, Derli; PERIUS, Vergílio. Cooperativismo e cooperativa. In: CATANI, Antônio David (Org). A outra economia. Veraz Editores. Porto Alegre, 2003

SCHWARZ, Rodrigo Garcia. Trabalho escravo: a abolição necessária. São Paulo:LTr,, 2008

SENTO-SÉ, Jairo Lins de Albuquerque. Trabalho escravo no Brasil. São Paulo: LTr, 2001.

SILVA, Cristiane de Melo M.S.Do escravismo colonial ao trabalho forçado atual.A supressão dos direitos sociais fundamentais.1 $1^{\mathrm{a} e d}$. Curitiba: LTr, 2009.

SIMÓN, Sandra Lia; MELO, LuisAntonio Camargo de. Produção, consumo e escravidão restrições econômicas e fiscais. Lista suja, certificados e selos de garantia de respeito às leis ambientais trabalhistas na cadeia produtiva. In: VELLOSO, Gabriel; FAVA, Marcos Neves (coord.). Trabalho Escravo Contemporâneo: o desafio de superar a negação. São Paulo: LTr, 2006.

SINGER, Paul. Economia Solidária. In: CATANI, Antônio David (Org). A outra economia. Veraz Editores. Porto Alegre, 2003. 
Site do INSTITUTO DE OBSERVATÓRIO SOCIAL:

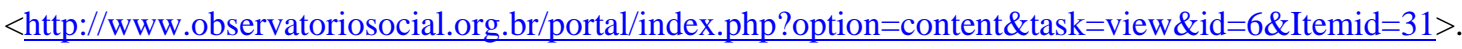

Site da OIT: < $\underline{\text { http://www.oitbrasil.org.br/>. }}$.

Site da ONG Repórter Brasil: <http://www.reporterbrasil.org.br/>.

Site do Senado Federal: < $\underline{\text { http://www.senado.gov.br/> }}$.

SOUSA, Rainer. $\quad$ Brasil Escola. $\quad$ Disponível em :http://www.brasilescola.com/historiab/escravidao-no-brasil.htm

VIANA, Márcio Túlio; FONSECA, Mariana Martins de Castilho. A “LISTA SUJA” E O TRABALHO ESCRAVO. AS PORTARIAS MTE $n^{\circ}$ 540/2004 E MIN $n^{\circ}$ 1.150/2003. São Paulo, 2010.

VIANA, Márcio Túlio. Trabalho escravo e lista suja: um modo original de se remover uma mancha. In: Possibilidades jurídicas de combate à escravidão contemporânea. Brasília: Organização Internacional do Trabalho, 2007.

Congresso em Paris em 2008.

.Debate Ideológico y Legislación Laboral.Texto apresentado em 